Pacific Journal of Mathematics

CLIFFORD VECTORS 


\section{CLIFFORD VECTORS}

\section{Curtis M. Fulton}

In this paper we present a generalization of parallel vector fields in a Riemannian space. As it turns out, such fields exist in spaces of constant positive curvature.

Restricting ourselves to a Riemannian 3-space throughout, we need the oriented third-order tensor [3, p. 249]

$$
\eta_{i j h}=[\operatorname{sgn}(g) g]^{1 / 2} \varepsilon_{i j h} .
$$

whose covariant derivative vanishes [3, pp. 251-252]. The latter fact is best ascertained by the use of geodesic coordinates. If we write the determinant of the metric tensor with the aid of permutation symbols we also find without difficulty

$$
g^{p q} \eta_{i j p} \eta_{k h q}=g_{h j} g_{i k}-g_{h i} g_{j k} .
$$

DeFinition. Let the direction of a vector field at any point be that of the unit vector $\boldsymbol{V}$. The field is said to consist of Clifford vectors if

$$
V_{i, j}=L_{i j h}^{\eta} V^{h}, \quad L \neq 0 .
$$

THEOREM. If the Riemannian curvature $K$ is constant and equal to $L^{2}$, the system of equations ( 2 ) is completely integrable. If, at any point, solutions of (2) exist in all directions, then $K=L^{2}=$ const.

It is known that integrability conditions for (2) are obtained using covariant differentiation. Hence, on account of a Ricci identity [3, p. 83] and (1) we have

$$
L_{, k} \eta_{i j h} V^{h}-L_{, j} \eta_{i k h} V^{h}+L^{2}\left(g_{h j} g_{i k}-g_{h k} g_{i j}\right) V^{h}=R_{h i j k} V^{h} .
$$

If the Riemannian curvature is constant [3, p. 112],

$$
R_{h i j k}=K\left(g_{h j} g_{i k}-g_{h k} g_{i j}\right)
$$

and conditions (3) are identically satisfied. This proves the first part of our theorem.

For proof of the second part we multiply (3) by $W^{i} V^{j} W^{k}$ and get

$$
L^{2}\left(g_{h j} g_{i k}-g_{h k} g_{i j}\right) V^{h} W^{i} V^{j} W^{k}=R_{h i j k} V^{h} W^{i} V^{j} W^{k} .
$$

Thus $L^{2}$ is the Riemannian curvature associated with the unit vectors

Received August 29, 1963. 
$\boldsymbol{V}, W[3$, p. 95]. Assume now that $W$ is a solution of (2) and $M$ the corresponding scalar factor. Then the above curvature is also equal to $M^{2}$. Continuing this process we conclude from Schur's theorem $\left[3\right.$, p. 112] that the curvature is constant and because of (4) that $K=L^{2}$.

To conclude, we demonstrate a geometric property of Clifford vectors justifying the name chosen for them. Let $t$ be the unit tangent to a geodesic and $\boldsymbol{U}$ a unit vector which undergoes a parallel displacement along the geodesic. Hence $U^{i}{ }_{, j} t^{j}=0$ and $\boldsymbol{U}$ remains in a plane passing through the geodesic [1, p. 161]. On the other hand, because of (2), $V_{i, j} t^{i} t^{j}=0$ which shows that a Clifford vector, propagaged along the geodesic, is inclined at a constant angle to it. Letting $\cos \theta=U^{i} V_{i}$, we see that

$$
-\sin \theta d_{s} \theta=L \eta_{i j h} U^{i} t^{j} V^{h}
$$

We now make the simplifying assumption that both $\boldsymbol{U}$ and $\boldsymbol{V}$ are perpendicular to $t$. In this case the vector $\eta_{i j h} U^{i} V^{h}$ has the direction of $t$ and using (1) we find its length to be $\sin \theta$. Thus $d_{s} \theta= \pm L$ and the Clifford vector rotates about the geodesic in either sense through an angle proportional to the displacement. This property may be used to define the Clifford parallels or paratactic lines in elliptic 3-space [2, p. 108].

\section{REFERENCES}

1. A. Duschek, W. Mayer, Lehrbuch der Differentialgeometrie, Band II, Teubner, Leipzig und Berlin, 1930.

2. D. M. Y. Sommerville, The elements of non-Euclidean geometry, Dover, New York, 1958.

3. J. L. Synge, A. Schild, Tensor calculus, University of Toronto Press, Toronto, 1959.

UNIVERSITY OF CALIFORNIA, DAVIS 


\section{PACIFIC JOURNAL OF MATHEMATICS}

\section{EDITORS}

\author{
Robert Osserman \\ Stanford University \\ Stanford, California
M. G. Arsove
University of Washington
Seattle 5 , Washington

\author{
J. DugundJI \\ University of Southern California \\ Los Angeles 7, California
}

Lowell J. Paige

University of California

Los Angeles 24, California

\section{ASSOCIATE EDITORS}
E. F. BECKENBACH
B. H. NeumanN
F. WOLF
K. YOSIDA

\section{SUPPORTING INSTITUTIONS}

\author{
UNIVERSITY OF BRITISH COLUMBIA \\ CALIFORNIA INSTITUTE OF TECHNOLOGY \\ UNIVERSITY OF CALIFORNIA \\ MONTANA STATE UNIVERSITY \\ UNIVERSITY OF NEVADA \\ NEW MEXICO STATE UNIVERSITY \\ OREGON STATE UNIVERSITY \\ UNIVERSITY OF OREGON \\ OSAKA UNIVERSITY \\ UNIVERSITY OF SOUTHERN CALIFORNIA
}

\author{
STANFORD UNIVERSITY \\ UNIVERSITY OF TOKYO \\ UNIVERSITY OF UTAH \\ WASHINGTON STATE UNIVERSITY \\ UNIVERSITY OF WASHINGTON \\ * * * * \\ AMERICAN MATHEMATICAL SOCIETY \\ CALIFORNIA RESEARCH CORPORATION \\ SPACE TECHNOLOGY LABORATORIES \\ NAVAL ORDNANCE TEST STATION
}

Mathematical papers intended for publication in the Pacific Journal of Mathematics should by typewritten (double spaced), and on submission, must be accompanied by a separate author's résumé. Manuscripts may be sent to any one of the four editors. All other communications to the editors should be addressed to the managing editor, L. J. Paige at the University of California, Los Angeles 24, California.

50 reprints per author of each article are furnished free of charge; additional copies may be obtained at cost in multiples of 50 .

The Pacific Journal of Mathematics is published quarterly, in March, June, September, and December. Effective with Volume 13 the price per volume (4 numbers) is $\$ 18.00$; single issues, $\$ 5.00$. Special price for current issues to individual faculty members of supporting institutions and to individual members of the American Mathematical Society: $\$ 8.00$ per volume; single issues $\$ 2.50$. Back numbers are available.

Subscriptions, orders for back numbers, and changes of address should be sent to Pacific Journal of Mathematics, 103 Highland Boulevard, Berkeley 8, California.

Printed at Kokusai Bunken Insatsusha (International Academic Printing Co., Ltd.), No. 6, 2-chome, Fujimi-cho, Chiyoda-ku, Tokyo, Japan.

PUBLISHED BY PACIFIC JOURNAL OF MATHEMATICS, A NON-PROFIT CORPORATION

The Supporting Institutions listed above contribute to the cost of publication of this Journal, but they are not owners or publishers and have no responsibility for its content or policies. 


\section{Pacific Journal of Mathematics}

\section{Vol. 14, No. $3 \quad$ July, 1964}

Erik Balslev and Theodore William Gamelin, The essential spectrum of a class of ordinary differential operators . . . . . . . . . . . . . . . . . . . .

James Henry Bramble and Lawrence Edward Payne, Bounds for derivatives in

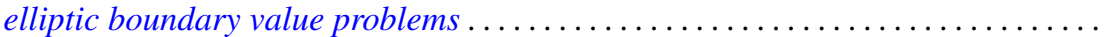

Hugh D. Brunk, Integral inequalities for functions with nondecreasing

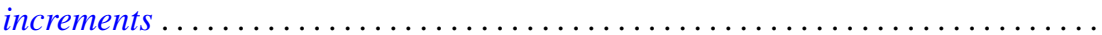

William Edward Christilles, A result concerning integral binary quadratic

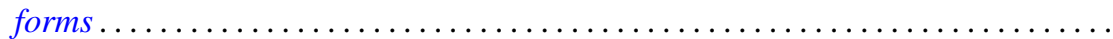

Peter Crawley and Bjarni Jónsson, Refinements for infinite direct decompositions of

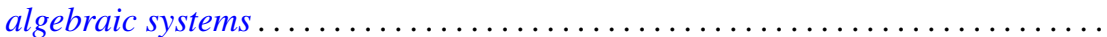

Don Deckard and Carl Mark Pearcy, On continuous matrix-valued functions on a Stonian space.

Raymond Frank Dickman, Leonard Rubin and P. M. Swingle, Another

characterization of the $n$-sphere and related results $\ldots \ldots \ldots \ldots \ldots \ldots$

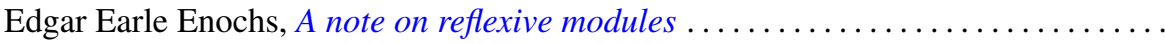

Vladimir Filippenko, On the reflection of harmonic functions and of solutions of the

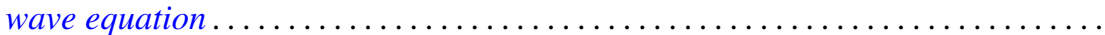

Derek Joseph Haggard Fuller, Mappings of bounded characteristic into arbitrary

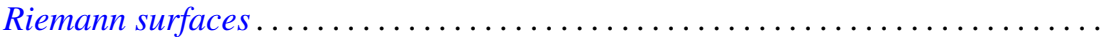
895

Curtis M. Fulton, Clifford vectors . . . . . . . . . . . . . . . . . . . . . . . . . . . . . . 917

Irving Leonard Glicksberg, Maximal algebras and a theorem of Radó . .

919

Kyong Taik Hahn, Minimum problems of Plateau type in the Bergman metric

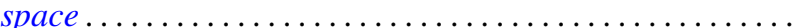

A. Hayes, A representation theory for a class of partially ordered rings...

J. M. C. Joshi, On a generalized Stieltjes trasform

J. M. C. Joshi, Inversion and representation theorems for a generalized Laplace transform ...

Eugene Kay McLachlan, Extremal elements of the convex cone $B_{n}$ of functions ...

Robert Alan Melter, Contributions to Boolean geometry of p-rings ...

James Ronald Retherford, Basic sequences and the Paley-Wiener criterion . . . . . . . 1019

Dallas W. Sasser, Quasi-positive operators. .

Oved Shisha, On the structure of infrapolynomials with prescribed coefficients ..

Oved Shisha and Gerald Thomas Cargo, On comparable means

Maurice Sion, A characterization of weak ${ }^{*}$ convergence ........

Morton Lincoln Slater and Robert James Thompson, A permanent inequality for

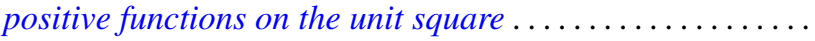

David A. Smith, On fixed points of automorphisms of classical Lie algebras ...

Sherman K. Stein, Homogeneous quasigroups ................

J. L. Walsh and Oved Shisha, On the location of the zeros of some infrapolynomials with prescribed coefficients .

Ronson Joseph Warne, Homomorphisms of $d$-simple inverse semigroups with identity . 